\title{
Forgiveness, Religiousness, and Life Satisfaction: An Empirical Study on Turkish and Jordanian University Students
}

\author{
Ali Ayten ${ }^{1}$ \\ Marmara University
}

\author{
Hamza Ferhan ${ }^{2}$ \\ Necmettin Erbakan University
}

\begin{abstract}
Forgiveness has been examined in the science of psychology and its sub-departments like psychology of religion with the focus on the interrelations between personality, attachment, health, religiosity, and so on. In this article, forgiveness has been investigated in the context of its relation with religiosity and life satisfaction. The main aim of the study is to delineate the role of religiosity on forgiveness and life satisfaction. Furthermore, the relationship between forgiveness and demographics (gender and age) and the effect of cultural differences on forgiveness have also been investigated in this study. A further goal of this paper will be to describe the effect of forgiveness on life satisfaction. In order to discern the abovementioned goals, the Interpersonal Forgiveness Scale and Life Satisfaction Scale were applied to a sample of 295 students from Yarmouk University in Irbid, Jordan, and Marmara University in Istanbul, Turkey. According to the findings, female students had higher means in "vengeance," a sub-department of forgiveness, than male students. Female students were more likely to be satisfied with life than male students.
\end{abstract}

Keywords

Religiosity • Life satisfaction • Interpersonal forgiveness • Comparative study

Affetme, Dindarlık ve Hayat Memnuniyeti İlișkisi: Türk ve Ürdünlü Üniversite Öğrencileri Üzerine Bir Araştırma

$\mathrm{O} z$

Affetme; sağlık, kişilik, bağlanma ve dindarlıkla ilişkilendirilerek başta din psikolojisi olmak üzere psikolojinin farklı alt dallarında incelenmiștir. Bu makalede affetme, dindarlık ve hayat memnuniyetiyle (yaşam doyumu) ilişkisi bağlamında araştırılmaktadır. Araştırmanın temel amacı dindarlığın hem affetme hem de hayat memnuniyeti üzerindeki rolünün belirlenmesi, aynı zamanda affetmenin hayat memnuniyeti üzerindeki rolünün tespitidir. Ayrıca araştırmada cinsiyet ve yaşın affetme eğilimindeki rolü ele alınmıș, Ürdün ve Türkiye'den iki farklı örneklem seçilerek kültürel bir karșılaştırma da hedeflenmiştir. Araştırma örneklemi İstanbul ve İrbid'de okuyan üniversite öğrencilerinden oluşmaktadır. Araştırmaya katılanların 223'i $(\% 75,6)$ kadın, 72'si $(\% 24,4)$ erkektir. Katılımcıların yaşları, 17 ile 50 arasında değişmektedir. Yaş ortalaması ise 22'dir. Örnekleme, Affetme Eğilimi Ölçeği ve Hayat Memnuniyeti Ölçeği uygulanmıştır. Elde edilen bulgulara göre, affetme eğiliminin öç alma alt boyutunda cinsiyetin anlamlı bir farklılık oluşturduğu anlaşılmıştır.

Anahtar Kelimeler

Dindarlık • Hayat memnuniyeti • Kişilerarası affetme • Karşılaştırmalı araştırma

1 Correspondece to: Ali Ayten (PhD), Psychology of Religion Department, Theology Faculty, Marmara University, Mahir İz Cad. No. 2 Altunizade Üsküdar, İstanbul Turkey.

Email: aliayten@marmara.edu.tr

2 Sociology of Religion Program, Institute of Social Sciences, Necmettin Erbakan University, Konya Turkey. Email: hamza_f@hotmail.com

Citation: Ayten, A., \& Ferhan, H. (2016). Forgiveness, religiousness, and life satisfaction: An empirical study on Turkish and Jordanian university students. Spiritual Psychology and Counseling, 1, 79-84. http://dx.doi.org/10.12738/spc.2016.1.0006 
Forgiveness was a topic that had received much attention in the fields of religion and philosophy in the past. Many role models for forgiveness exist in holy books of different religions (Ayten, 2014; Sambur, 2001). Philosophers and theologians evaluated forgiveness from religious and philosophical points of view. Theologians highlighted the importance of forgiveness in religion for both the relationship between God and the individual and between people themselves. Furthermore, theologians not only focused on this importance but also referred to forgiveness as the fuel that maintains these relations (Al-A'sfahani, 2002). Various philosophers have considered forgiveness as a virtue (Comte-Sponville, 2012). For instance, Muslim philosophers also confirmed theologians' notions as well as adding detailed descriptions of forgiveness. Al-Tûsî (2007, p. 96) classified forgiveness as virtue under generosity (karam) and defined it as "abandoning the punishment of a transgression even though one has the ability to do this." Moreover, Al-A'sfahani (2009, p. 257) interrelated forgiveness ('afv) with the virtue of clemency (hilm) and defined it as "not punishing a transgressor for their transgression;" forgiveness is accepted as an aspect of the virtue of clemency. Worthington, Witvliet, Pietrini, and Miller (2007), conceptualized forgiveness as having both cognitive and emotional components. Psychologists Christopher Peterson and Martin Seligman (2004, p. 30) has classified forgiveness within the value of temperance. Social scientists began studying forgiveness from the psychological perspective in the 1960s. After the development of positive psychology, it was accepted as one of the most important virtues and studied in relation to different variables such as religiousness, health, personality, and more (Ayten, 2009; Egan \& Todorov, 2009; Elliott, 2011; Hirsch, Webb, \& Jeglic; 2011; Lewis, 2005; Rye \& Pargament; 2002; Toussaint \& Friedman, 2009; Toussaint, Owen, \& Cheadle, 2012; Van Dyke \& Elias, 2007; Webb, Chickering, Colburn, \& Heisler, 2005).

This paper intends to examine the relationship between religiosity, forgiveness, and life satisfaction. At the same time, it aims to investigate the links between gender, country, and the three variables mentioned above. In this article, the following hypotheses have been constructed to address the aims of the research:

$\left(H_{p}\right)$ There are positive relationships between gender, forgiveness, religiosity, and life satisfaction.

$\left(H_{l d}\right)$ Women score higher than men in interpersonal forgiveness, religiosity, and life satisfaction.

( $\left.\mathrm{H}_{2}\right)$ There is no relationship between different countries as far as forgiveness, religiosity, or life satisfaction.

$\left(H_{3}\right)$ There is a positive relationship between religiosity and life satisfaction.

$\left(H_{4}\right)$ There is a positive relationship between religiosity and forgiveness.

$\left(H_{5}\right)$ There is a positive relationship between forgiveness and life satisfaction. 


\section{Method}

The survey method and questionnaire technique were used in this research. The "Islamic Religiosity Measure-Short Form" and "Interpersonal Forgiveness Scale" were performed on the subjects. Analyses of factor, reliability, t-test, and regression were used for data analysis.

\section{Participants}

Of the university students studying in Istanbul, Turkey, and Irbid, Jordan, 295 participants were recruited. The non-random snowball sampling technique was used to collect data.

Of the sample, $59 \%(N=174)$ were Turkish and $41 \%(N=121)$ were Jordanian. For gender, $75.6 \%(N=223)$ were females and $24.4 \%(N=72)$ were males. The average age of the study participants was 22 years $(S D=4.3)$, and their ages ranged from 17 to 50 years old.

\section{Measures}

Background information. Participants responded to several demographic questions that provided data on age, gender, country, marital status, and faculty type.

Religiosity. In order to measure the level of subjective religiosity of students, one question was utilized: "How do you evaluate your level of religiosity?" The question measured participants' religiosity on a seven-point scale ranging from 1 to 7 . A " 1 " indicated a low level of religiosity, and a "7" indicated a high level.

Forgiveness. Students' inclined level of forgiveness was measured by the Interpersonal Forgiveness Scale. Reliability and validity analyses were conducted by Ayten (2009). The Kaiser-Mayer-Olkin parameter and Bartlett test showed the suitability of data for factor analysis $\left[K M O=.88, x^{2}=1894.523, p=.000\right]$. Cronbach's alpha coefficients for the scale were acceptable (Interpersonal Forgiveness total $\alpha=.87$; avoidance $\alpha=.83$; hopefulness $\alpha=.74$, and vengeance $\alpha=.71$ ). The findings from the factor and reliability analyses showed that the measure was acceptable and useable for assessing people's propensity towards forgiveness (see Ayten, 2009). In this study, the question of "I investigate the reason behind their deed" was removed from the scale because of its low factor loading. The scale was translated into Arabic by the researchers to measure the level of forgiveness of the Jordanian students. A new reliability analysis was conducted for this study. Cronbach's alpha coefficients for the measure were acceptable (Interpersonal Forgiveness total $\alpha=.839$; avoidance $\alpha=.754$; hopefulness $\alpha=.766$, and vengeance $\alpha=.694$ ).

Life satisfaction. The Satisfaction with Life Scale (Diener, Emmons, Larsen, \& Griffin, 1985) was used to measure the participants' level of life satisfaction. 
The scale was translated into Turkish by Ayten (2012). The Kaiser-Mayer-Olkin parameter and Bartlett test were found to be acceptable in terms of suitability of data for factor analysis $\left[K M O=.81, x^{2}=323,367, p=.000\right]$. The Arabic version of the scale was used for the Jordanian students. The scale was translated into Arabic by Abdel-Khalek (2008). Cronbach's alpha coefficient for the scale was found to be $\alpha$ $=.83$ and the correlation coefficients showing the relations among items in the scale ranged between $r=.34$ and $r=.73$.

\section{Procedure}

Data from the present study was collected between May and June of 2015 from students studying in Yarmouk University in Irbid, Jordan, and Marmara and Istanbul Universities in Istanbul, Turkey. The sample was recruited using the non-random snowball sampling technique. Questionnaires were distributed to participants in the classrooms. The researcher informed the participants about the objectives of the study and what their participation would entail. If needed, the researcher also answered participants' questions regarding the study and the questionnaire. Completion of the questionnaire took approximately 15 minutes based on voluntary participation.

\section{Results}

\section{Religiosity, Forgiveness, Life Satisfaction, and Gender}

In the present research, the independent sample t-test was carried out in order to examine whether or not religiosity, forgiveness, and life satisfaction were related to gender. The results of $t$-test analysis are presented in Table 1.

\begin{tabular}{|c|c|c|c|c|c|}
\hline \multicolumn{6}{|c|}{$\begin{array}{l}\text { Table } 1 \\
\text { Forgiveness, Religiosity, Life Satisfaction according to Gender }\end{array}$} \\
\hline Dependent Variables & Gender & $M$ & $S D$ & $t$ & $p$ \\
\hline \multirow{2}{*}{ Forgiveness } & Male $(N=72)$ & 3.63 & .53 & \multirow{2}{*}{1.790} & \multirow{2}{*}{.090} \\
\hline & Female $(N=223)$ & 3.75 & .55 & & \\
\hline \multirow{2}{*}{ Life Satisfaction } & Male $(N=72)$ & 4.34 & 4.3 & \multirow{2}{*}{-2.721} & \multirow{2}{*}{.008} \\
\hline & Female $(N=223)$ & 4.78 & 4.7 & & \\
\hline \multirow{2}{*}{ Religiosity } & Male $(N=72)$ & 4.31 & 1.26 & \multirow{2}{*}{.430} & \multirow{2}{*}{.668} \\
\hline & Female $(N=223)$ & 4.24 & 1.19 & & \\
\hline
\end{tabular}

Females $(M=3.75, S D=.55)$ scored higher on the forgiveness scale than males $(M=3.63, S D=.53)$. However, the difference between the two groups in terms of gender did not reach a level of statistical significance $\left(t_{(123.054)}=-1.790, p=.090\right)$.

Females $(M=4.78, S D=4.7)$ recorded higher life-satisfaction scores than males $(M=4.34, S D=4.3)$. The difference between the two groups for life satisfaction was statistically significant $\left(t_{(110.728)}=-2.721 ; p=.008\right)$. 
In subjective religiosity no gender differences were found between males and females $\left(t_{(114.806)}=.430 ; p=.668\right)$.

\section{Religiosity, Forgiveness, Life Satisfaction, and Country}

The independent sample $t$-test was carried out in order to assess the differences between Jordanian and Turkish students in subjective religiosity, life satisfaction, and forgiveness. The results of $t$-test analysis are presented in Table 2.

\begin{tabular}{|c|c|c|c|c|c|}
\hline \multicolumn{6}{|l|}{ Table 2} \\
\hline \multicolumn{6}{|c|}{ Forgiveness, Religiosity, Life Satisfaction according to Country } \\
\hline Dependent Variables & Samples & $M$ & $S D$ & $t$ & $p$ \\
\hline \multirow{2}{*}{ Forgiveness } & Turkish $(N=174)$ & 3.79 & .52 & \multirow{2}{*}{2.637} & \multirow{2}{*}{.009} \\
\hline & Jordanian $(N=121)$ & 3.63 & .56 & & \\
\hline \multirow{2}{*}{ Religiosity } & Turkish $(N=174)$ & 4.95 & .94 & \multirow{2}{*}{16.299} & \multirow{2}{*}{.000} \\
\hline & Jordanian $(N=121)$ & 3.26 & .77 & & \\
\hline \multirow{2}{*}{ Life Satisfaction } & Turkish $(N=174)$ & 4.71 & 1.04 & \multirow{2}{*}{.507} & \multirow{2}{*}{.613} \\
\hline & Jordanian $(N=121)$ & 3.64 & 1.29 & & \\
\hline
\end{tabular}

Turkish students recorded higher forgiveness scores $(M=3.79, S D=.52)$ than their Jordanian counterparts $(M=3.63, S D=.56)$. Moreover, the difference between the two groups was statistically significant $\left(t_{(246.615)}=2.637, p=.009\right)$.

The significant statistical difference between the two groups was indicated within subjective religiosity $\left(t_{(280.470)}=16.299, p=.000\right)$. The Turkish students $(M=4.95, S D=$ .94 ) recorded higher subjective religiosity than the Jordanian students $(M=3.26, S D=.77)$.

As for life satisfaction, no significant difference was found between the two groups $\left(t_{(221.390)}=.507, p=.613\right)$.

\section{The Relationship between Religiosity and Forgiveness}

Regression analysis (enter method) was used to assess whether religiosity has an effect on interpersonal forgiveness. The results of regression analysis are presented in Table 3.

Table 3

Linear Regression to Predict Forgiveness with Religiosity

\begin{tabular}{ccccc}
\hline DV: Forgiveness & $\beta$ & $p$ & $R^{2}(p)$ & $\Delta R^{2}(p)$ \\
\hline & .265 & .000 & $.070(.000)$ & $.067(.000)$ \\
\hline
\end{tabular}

According to regression analysis, religiosity was a significant predictor of interpersonal forgiveness. Religiosity accounted for $6 \%$ of the variance in forgiveness $\left(\Delta R^{2}=.067, F=22.179, p=.000\right)$. In regards to the beta coefficients, a positive correlation was found between religiosity and forgiveness $(\beta=.265, t=4.790, p=$ $.000)$. The results indicated that interpersonal forgiveness increased as religiosity 
increased. These findings support the research hypothesis that there is positive relationship between forgiveness and religiosity $(H 4)$.

\section{Religiosity and Life Satisfaction}

In order to assess the role of religiosity in life satisfaction, regression analysis was used. The results of regression analysis are presented in Table 4.

Table 4

Linear Regression of Religiosity as a Predictor of Life Satisfaction

\begin{tabular}{ccccc}
\hline DV: Life Satisfaction & $\beta$ & $p$ & $R^{2}(p)$ & $\Delta R^{2}(p)$ \\
\hline & .200 & .001 & $.040(.000)$ & $.037(.000)$ \\
\hline
\end{tabular}

According to the analysis, religiosity was a significant predictor of life satisfaction. Religiosity accounted only for $3 \%$ of the variance in forgiveness $\left(\Delta R^{2}=.037, F=\right.$ $12.230, p=.000)$. In regards to the beta coefficients, a positive correlation was found between religiosity and life satisfaction $(\beta=.200, t=3.497, p=.001)$. The results indicated that life satisfaction increased as religiosity increased. These findings support the research hypothesis that there is positive relationship between life satisfaction and religiosity $(H 3)$.

\section{Forgiveness and Life Satisfaction}

Simple linear regression analysis was used to measure the effect of forgiveness on life satisfaction. The results of regression analysis are presented in Table 5.

Table 5

Linear Regression of Forgiveness as a Predictor of Life Satisfaction

\begin{tabular}{ccccc}
\hline DV: Life Satisfaction & $\beta$ & $p$ & $R^{2}(p)$ & $\Delta R^{2}(p)$ \\
\hline & .121 & .038 & $.015(.000)$ & $.011(.000)$ \\
\hline
\end{tabular}

According to regression analysis, which was conducted to find the role of forgiveness in life satisfaction, forgiveness was found to be a significant predictor of life satisfaction. Forgiveness only accounted for $1 \%$ of the variance in life satisfaction $\left(\Delta R^{2}=.011, F=4.344, p=.000\right)$. In regard to the beta coefficients, a positive correlation was found between forgiveness and life satisfaction $(\beta=.121, t=2.084, p=.038)$. The results indicated that life satisfaction increased as forgiveness increased. These findings support the research hypothesis that there is positive relationship between life satisfaction and forgiveness (H5).

\section{Discussion and Conclusion}

The main aim of this paper was to examine the relationship between religiosity, forgiveness, and life satisfaction within the sample of university students. Moreover, 
the aim was to discern the role of religion and country in students' religiosity, forgiveness, and life satisfaction. The questions of "What is the role of religiosity in forgiveness?" and "How do forgiveness and religiosity promote life satisfaction?" were answered through a comparison study which was carried out on Muslim samples from Turkey and Jordan.

The findings showed no statistically significant relationship to exist between gender and religiosity. This finding did not support the hypothesis regarding the relationship between gender and religiosity (H1). This finding was also not consistent with other studies which had been conducted on different samples. On the contrary, various studies have shown a statistically significant relationship to exist between gender and religiosity. Most studies on forgiveness have indicated that females score higher in religiosity than males (Ayten, 2010; el-Mehârib, 2003; Hucâr \& Abdulkerim, 2006; Yap1c1, 2007; Walter \& Davie, 1998).

The findings from this study indicated that males recorded higher scores in the forgiveness sub-dimension of vengeance than females. This showed that female students were more likely to forgive than males. This finding also shows consistency with some other studies. For instance, Miller, Worthington, and McDaniel (2008) examined 70 studies investigating the link between gender and forgiveness and found that females had a higher inclination towards forgiveness than males.

According to the current findings, females scored higher in life satisfaction than males. This finding is consistent with some studies (e.g., Ayten, 2012; Patel, Ramgoon, \& Paruk, 2009), while inconsistent with other studies (Abdel-Khalek \& al-Nayal, 2015; Ayten \& Gashi, 2012; Idemudia \& Mahri, 2011; Hamîse, 2013).

This study hypothesized that no difference exists between Turkish and Jordanian students in terms of inclination towards forgiveness, life satisfaction, or subjective religiosity due to their similar cultural and religious backgrounds (H2). However, Turkish students had higher scores in forgiveness than their Jordanian counterparts. Many previous comparison studies have shown that cultural differences play a role in forgiveness and life satisfaction (Ayten \& Gashi, 2012; Bagnulo, Munoz-Sastre, \& Mullet, 2009; Devsirî, 201; Munoz-Sastre, Vinsonneau, Neto, Girard, \& Mullet, 2003). Although Krause (2012), has documented both significant and non significant differences on forgiveness levels with respect to ethnic identity; and Paz, Neto, and Mullet (2008) study has shown no significant differentiation with respect to ethnicity.

Depending on the current findings or the findings from other studies, one could conclude that (a) intensity and forms of forgiveness might change according to race and culture, or (b) differences between collectivist and individualistic societies are not always valid as far as life satisfaction and forgiveness. 
Many previous studies have shown a positive relationship to exist between religiosity and forgiveness (Ayten, 2009; Escher, 2013; Lutjen, Silton, \& Flannelly, 2012; Uysal, 2015). Similarly, the findings of the current study have demonstrated a statistically significant relationship to exist between religiosity and interpersonal forgiveness.

Religiosity and forgiveness was hypothesized to have positive effects on life satisfaction (H3 and H5). Supporting these hypotheses, the findings showed that religiosity and forgiveness relate positively to life satisfaction. These findings were consistent with many other findings obtained from previous studies (Ayten, 2014; Ayten \& Gashi, 2012; Egan \& Todorov, 2009; Ismail \& Desmukh, 2012; Macaskill, 2012; Suhail \& Chaudry, 2004; Toussaint \& Friedman, 2009; Webb, Dula, \& Brewer, 2012).

The current study was the first unique comparison study on the relationship between religiosity, forgiveness, and life satisfaction using two Muslim samples from Turkey and Jordan. Hence, it had a number of limitations. The first limitation was in regard to the way the sample was constituted. It did not represent all age groups and was limited to university students. It might be beneficial in the future to extend the sample to wider groups. The second limitation was in regard to measurement. In order to assess participants' religiosity, a one-item questionnaire was used. It might be quite useful to measure religious inclinations of samples with an Islamic Religiosity Scale consisting of various questions and dimensions.

\section{References}

Abdel-Khalek, M. A. (2008). er-Ridâ ani'l hayâti fi'l müctemai'l Kuveytî [Life satisfaction in Kuweytian society]. Dirâsât Nefsiyye, 18(1), 121-135.

Abdel-Khalek, A., \& al-Nayal, M. (2015). Satisfaction with life among young adults in four Arab countries. Psychological Reports: Sociocultural Issues in Psychology, 117(3), 931-939.

Al-A'sfahani, R. (2002). Müfredât: Kur'ân kavramları sözlüğü [Mufradaat: Dictionary of Quranic concepts] (Y. Türker, trans.). İstanbul, Turkey: Pınar Yayınları.

Al-A'sfahani, R. (2009). Erdemli yol [Virtues way] (M. Tan, trans.). İstanbul, Turkey: İz Yayıncilik.

Al-Tûsî, N. (2007). Ahlâk-ı nâsırî (A. Gafarov \& Z. Şükürov, trans.). İstanbul, Turkey: Litera Yayıncilik.

Ayten, A. (2009). Affedicilik ve din: Affetme eğilimi ve dindarlıkla ilişkisi üzerine ampirik bir araştırma [Forgiveness and religion: A study on the relationship between forgiveness and religiosity]. Marmara Üniversitesi İlahiyat Fakültesi Dergisi, 37(2), 111-128.

Ayten, A. (2010). Empati ve din: Türkiye'de yardimlaşma ve dindarlı üzerine psikososyolojik bir araştırma. İstanbul, Turkey: İz Yayınc1lı.

Ayten, A. (2012). Tanrıya sı̆̆ı̆mmak: Dini başa çıkma üzerine psiko-sosyal bir araştırma [Take shelter to God: A Study on religious coping]. İstanbul, Turkey: İz Yayınc1lık.

Ayten, A. (2014). Din ve sağlık: Bireysel dindarlık, sağlık davranışları ve hayat memnuniyeti ilişkisi üzerine bir araştırma [Religion and health: A study on individual religiosity, health behaviours and life satisfaction]. Din Bilimleri Akademik Araş̧tırma Dergisi, 13(3), 7-31. 
Ayten, A., \& Gashi, F. (2012). Affetme ve hayat memnuniyeti üzerine karşılaştırmalı bir araştırma [A comparison study on forgiveness and life satisfaction]. Balkan Araştırmaları Dergisi, 3(2), 11-36.

Bagnulo, A., Munoz-Sastre, M., \& Mullet, E. (2009). Conceptualizations of forgiveness: A Latin America-Western Europe comparison. Universitas Psychologica, 8(3), 673-682.

Comte-Sponville, A. (2012). Büyük erdemler risalesi (I. Ergüden, trans.). İstanbul, Turkey: İletişim Yayınları.

Devsirî, İ. (2012). el-Afv ve alâkatühu bi infiâli'l gadab lede ayine mi tâlibât camiati Ümmü'l Kura bi Mekkete'l Mükerreme (Master's thesis, Ümmül Kura University, Mekkei Mükerreme, Saudi Arabia).

Diener, E., Emmons, R. A., Larsen, R. J., \& Griffin, S. (1985). The satisfaction with life scale. Journal of Personality Assessment, 49(1), 71-75.

Egan, L. A., \& Todorov, N. (2009). Forgiveness as a coping strategy to allow school students to deal with the effects of being bullied: Theoretical and empirical discussion. Journal of Social and Clinical Psychology, 28(2), 198-222.

Elliott, B. (2011). Forgiveness therapy: A clinical intervention for chronic disease. Journal of Religion and Health, 50, 240-247.

el-Mehârib, N. (2003). et-Tedeyyün ve'l-umr ve e'radi'l-ittirâbâti'n-nefsiyye lede murahikîn fi'l-memleketi'l-Arabiyyeti's-Suûdiyye. Mecelle külliyeti 'l-Adâb, 63(2), 197-229.

Escher, D. (2013). How does religion promote forgiveness? Linking beliefs, orientations, and practices. Journal for the Scientific Study of Religion, 52(1), 100-119.

Hamîse, K. (2013). el-İsticâbetü'l münâiye ve alâkatuhâ bi'd da'mi'l ictimâî'l müdreke ve'r rıda ani'l hayati lede meradâ's saratân (Doctoral dissertation, Camiatu el Hac el Hadar, Batne).

Hirsch, J. K., Webb, R., \& Jeglic, L. (2011). Forgiveness, depression, and suicidal behavior among a diverse sample of college students. Journal of Clinical Psychology, 67, 1-11.

Hucâr, B., \& Abdulkerim, S. (2006). et-teveccüh nahve't-tedeyyün lede talebeti'l-Câmiati'lİslâmiyye bi Gazze. Mecelletü'l- Câmiatü'l-İslâmî, 14(1), 269-289.

Idemudia, E. S., \& Mahri, S. (2011). Can gender, religion, education, age and personality predict willingness to forgive? Gender \& Behaviour, 9(1), 3766-3781.

Ismail, Z., \& Desmukh, S. (2012). Religiosity and psychological well-being. International Journal of Business and Social Science, 3(11), 20-28.

Krause, N. (2012). Studying forgiveness among older whites, older blacks, and older Mexican Americans. Journal of Religion, Spirituality, \& Aging, 24, 325-344.

Lewis, J. (2005). Forgiveness and psychotherapy: The prepersonal, the personal and the transpersonal. Journal of Transpersonal Psychology, 37(2), 124-141.

Lutjen, L. J., Silton, N. R., \& Flannelly, K. J. (2012). Religion, forgiveness, hostility and health: A structural equation analysis. Journal of Religion and Health, 51, 468-478.

Macaskill, A. (2012). Differentiating dispositional self- forgiveness from other-forgiveness: Associations with mental health and life satisfaction. Journal of Social and Clinical Psychology, 31(1), 28-50.

Miller, A. J., Worthington, E. L. Jr., \& McDaniel, M. A. (2008). Gender and forgiveness: A meta-analytic review and research agenda. Journal of Social and Clinical Psychology, 27(8), 843-876.

Munoz-Sastre, M., Vinsonneau, G., Neto, F., Girard, M., \& Mullet, E. (2003). Forgivingness and satisfaction with life. Journal of Happiness Studies, 4, 323-335. 
Patel, C. J., Ramgoon, S., \& Paruk, Z. (2009). Exploring religion, race and gender as factors in the life satisfaction and religiosity of young South African adults. South African Journal of Psychology, 39(3), 266-274.

Paz, R., Neto, F., \& Mullet, E. (2008). Forgiveness: A China-Western Europe comparison. The Journal of Psychology, 142(2), 147-157.

Peterson, C. \& Seligman, M. (2004). Character strengths and virtues: A handbook and classification. New York: Oxford University Pre

Rye, M. S., \& Pargament, K. I. (2002). Forgiveness and romantic relationships in college: Can it heal the wounded heart? Journal of Clinical Psychology, 58, 419-441.

Sambur, B. (2001). Forgiveness in Islam. Islam and Modern Age, 32(1), 55-68.

Suhail, K., \& Chaudry, H. (2004). Predictors of subjective well-being in an Eastern Muslim culture. Journal of Social and Clinical Psychology, 23(3), 359-376.

Toussaint, L., \& Friedman, P. (2009). Forgiveness, gratitude, and well-being: The mediating role of affect and beliefs. Journal of Happiness Studies, 10, 635-654.

Toussaint, L., Owen, A. D., \& Cheadle, A. (2012). Forgive to live: Forgiveness, health, and longevity. Journal of Behavioral Medicine, 35, 375-386.

Uysal, V. (2015). Genç yetişkinlerde affetme eğilimleri ve dinî yönelim/dindarlık [Forgiveness and religious orientation/religiosity on young adults]. Marmara Üniversitesi İlahiyat Fakültesi Dergisi, 48, 35-56.

Van Dyke, C. J., \& Elias, M. (2007). How forgiveness, purpose, and religiosity are related to the mental health and well-being of youth: A review of the literature. Mental Health, Religion \& Culture, 10(4), 395-415.

Walter, T., \& Davie, G. (1998). The religiosity of women in the modern West. The British Journal of Sociology, 49(4), 640-660.

Webb, J. R., Dula, C. S., \& Brewer, K. (2012). Forgiveness and aggression among college students. Journal of Spirituality in Mental Health, 14, 38-58.

Webb, M., Chickering, S. A., Colburn, T. A., Heisler, D., \& Call, S. (2005). Religiosity and dispositional forgiven. Review of Religious Research, 46(4), 355-370.

Worthington, E. L., Witvliet, C. V., Pietrini, P., \& Miller, A. J. (2007). Forgiveness, health, and well-being: A review of evidence for emotional versus decisional forgiveness, dispositional forgivingness, and reduced unforgiveness, Journal of Behavioural Medicine, 30, 291-302.

Yapıc1, A. (2007). Ruh sağlı̆̆l ve din: Psiko-sosyal uyum ve dindarlık [Mental health and religion: Psycho-social adjustment and religiosity]. Adana, Turkey: Karahan Yayınları. 